\title{
Gonococcal infection: the effect of educational counselling on patient compliance*
}

\author{
KAREN KRUSE GOODRICH \\ From St Mary's Hospital, London
}

SUMMARY Control of the spread of gonorrhoea requires considerable patient co-operation. A study of 100 consecutive patients with gonorrhoea attending a sexually transmitted diseases clinic was undertaken to determine whether improving a patient's understanding of their disease, its treatment, and the need for contact tracing increased the patient's willingness to attend for followup. The results indicated that although educational counselling improved the reattendance rate at follow-up it is debatable whether such a time-consuming and expensive method is justifiable economically.

\section{Introduction}

The steady resurgence of gonorrhoea since the late 1950 s is of such a magnitude that it is now the second most common infectious disease and is considered by an international group of specialists in the field of sexually transmitted disease to be pandemic. ${ }^{1}$ The situation in England is similar to that internationally with a progressive increase in the number of cases reported from clinics since the mid-1950s (table I). ${ }^{2}$

TABLE I New cases of gonorrhoea per 100000 population for years 1969-75

\begin{tabular}{ccccccc}
\hline 1969 & 1970 & 1971 & 1972 & 1973 & 1974 & 1975 \\
\hline $108 \cdot 26$ & $115 \cdot 72$ & $121 \cdot 26$ & $115 \cdot 28$ & $126 \cdot 10$ & $125 \cdot 06$ & $126 \cdot 91$ \\
\hline
\end{tabular}

These figures are probably a reliable indication of the prevalence of the disease in the population as, in contrast to other countries, few cases are treated by general practitioners in Britain. In areas where there is an efficient clinic service, most patients attend of their own accord or are referred. The figures from the Praed Street Clinic, St Mary's Hospital, London, (table II) give an indication of the scale of the problem in a busy central London clinic.

Measures for the control of gonorrhoea are based on (a) providing facilities for diagnosis and treatment, (b) tracing contacts of infected patients, and (c) health education.

*This paper was awarded the 1979 MSSVD Student Prize Address for reprints: Miss K K Goodrich, Flat 4, 36 Westbourne Terrace, London W2

Accepted for publication 24 July 1980
TABLE II Number of bacteriologically confirmed cases of gonorrhoea treated at the Praed Street Clinic per year (1959-77)

$\begin{array}{lllllllll}1959 & 1966 \quad 1970 & 1971 & 1972 & 1973 \quad 1974 & 1975 & 1976 & 1977\end{array}$

Men $\quad \begin{array}{llllllllll}2815 & 2366 & 3433 & 3347 & 2936 & 3538 & 3767 & 3761 & 4100 & 4162\end{array}$ $\begin{array}{lllllllllll}\text { Women } & 668 & 482 & 688 & 700 & 947 & 1237 & 1142 & 1210 & 1062 & 1227\end{array}$

At the Praed Street Clinic, patients with gonorrhoea are quickly and effectively treated with ampicillin $(3.5 \mathrm{~g})$ and probenecid $(1 \mathrm{~g})$. With their presenting symptoms (generally dysuria and discharge) relieved within three days, they need to be reasonably motivated to co-operate in the remaining aspects of the treatment programme-the tracing of their sexual contacts and attendance at three followup visits to the clinic - to ensure cure.

The present study was undertaken to determine whether patient compliance with the programme could be influenced by increasing the patient's knowledge of the disease and by explaining the necessity for tracing sexual contacts and attending for the follow-up appointments.

\section{Patients and methods}

During the study period from 1 January to 1 July 1978,100 consecutive patients who were diagnosed as having gonorrhoea were asked by the author if they would be willing to participate in the research project. Patients who did not reside in London and patients who were unable to speak English were excluded. Patients were selected when the investigator was available but were considered to be representative of the clinic population. 
The criterion for diagnosis was the identification of Gram-negative diplococci in smears taken from the urethra or rectum in men and from the urethra or cervix in women. The patients who thus presented for interview were assigned alternately to one of two groups designated "educated" and "uneducated". In both groups the patient was made to feel comfortable and the nature of the project was explained. The information shown in table III was obtained initially. From this point, the interview followed a different but set pattern in the two groups.

TABLE III Epidemiological data obtained from all patients

\begin{tabular}{|c|c|}
\hline Clinic No ... & Sexual orientation. . \\
\hline Age $\ldots \ldots \ldots \ldots \ldots \ldots \ldots$ & Marital state $\ldots \ldots \ldots \ldots \ldots \ldots$ \\
\hline Race...$\ldots$ & Religion ...... \\
\hline Education..$\ldots \ldots \ldots \ldots \ldots$ & No of children.... \\
\hline Occupation...$\ldots \ldots \ldots \ldots$ & Father's occupation ... \\
\hline \multicolumn{2}{|l|}{ Reason for attending the clinic. } \\
\hline No of previous consultations for & imilar problem . \\
\hline
\end{tabular}

"EDUCATED" GROUP

In the "educated" group, the patients' knowledge of their disease was assessed by obtaining answers to the following questions:

(1) What do you understand about your disease?

(2) What do you understand of the treatment you have been given?

(3) What do you understand you are to do about follow-up visits?

(4) What do you understand about the necessity for tracing any sexual contacts?

The interviewer then attempted to ensure that all patients understood: (a) the nature of the disease; (b) the method of transmission; (c) the natural course of the disease if untreated; (d) treatment; (e) avoidance of contracting the disease in the future; and ( $f$ ) the importance of contact tracing and attending for follow-up. This was accomplished by discussion with the patient followed by questions designed to find out how much the patient had understood. The patients were then given a score based on their knowledge at the end of the interview; the discussion was reinforced by giving the patients a copy of the pamphlet on gonorrhoea produced by the Health Education Council.

\section{"UNEDUCATED" GROUP}

Patients in the "uneducated" group were encouraged to enter into a discussion with the interviewer, during which the following questions were answered:

(1) Did the idea of attending a special clinic make you anxious/uncomfortable?

(2) If yes, would you feel less anxious/uncomfortable in the future?
(3) As a patient do you prefer to be described (i) by $\underset{\mathcal{\top}}{\overparen{T}}$ name; (ii) by number; (iii) don't care?

(4) Were the examination procedures and treatment what you expected?

(5) Have you ever received information about sexually transmitted diseases from (i) school; (ii) any of your family; (iii) friends; (iv) pamphlets; (v) magazines; (vi) a doctor; (vii) radio; (viii) television?

(6) If so, was the information that you received such that you understand (i) what the disease was that you were examined for; (ii) how serious a disease it is; (iii) how you contracted the disease; (iv) how you can avoid getting it in the future; (v) why it is necessary to treat the disease?

(7) As a result of your visit to the clinic what are your overriding impressions of the clinic?

These patients were involved in such a discussion primarily to ensure that they received as much time of and attention from the interviewer as those in the iv "educated" group, thereby minimising any likeli- $\vec{\omega}$ hood that a difference in compliance between the groups was due to the extra time and interest shown by the interviewer. An analysis of the answers was also undertaken to determine (a) the sources and quality of knowledge of sexually transmitted diseases among the patients; and (b) their reaction to the manner in which the special clinic was run.

Patients were interviewed only once. As most patients are given the complete course of antibiotics before leaving the clinic, treatment compliance in the study was measured by counting the number of attendances at follow-up appointments noted in the patients' clinic records.

\section{Results}

Two of the patients interviewed had to be excluded from the study because their records were not available for analysis. Data from 91 male and seven female patients were analysed.

\section{SEXUAL PREFERENCE}

The sexual preferences of the male patients were 옥 ascertained and all the data in the study were $\rightarrow$ computed on the basis of whether they were heterosexual, homosexual, or bisexual, as the large $\widetilde{N}$ number of homosexual and bisexual patients who attended the clinic might have formed a subgroup whose behaviour was different. In this study $25 \%$ of $\mathrm{C}$ the patients were male homosexuals and $10 \%$ male bisexuals.

\section{AGE}

Patients aged between 20 and 30 years accounted for $53 \%$ of the population; an additional $25 \%$ were between the ages of 31 and 40 . The large shift to the teenage population reported in many countries was not seen in this study (table IV). $\vec{\circ}$ , 
TABLE IV Distribution of age and sexual preference of patients in two groups

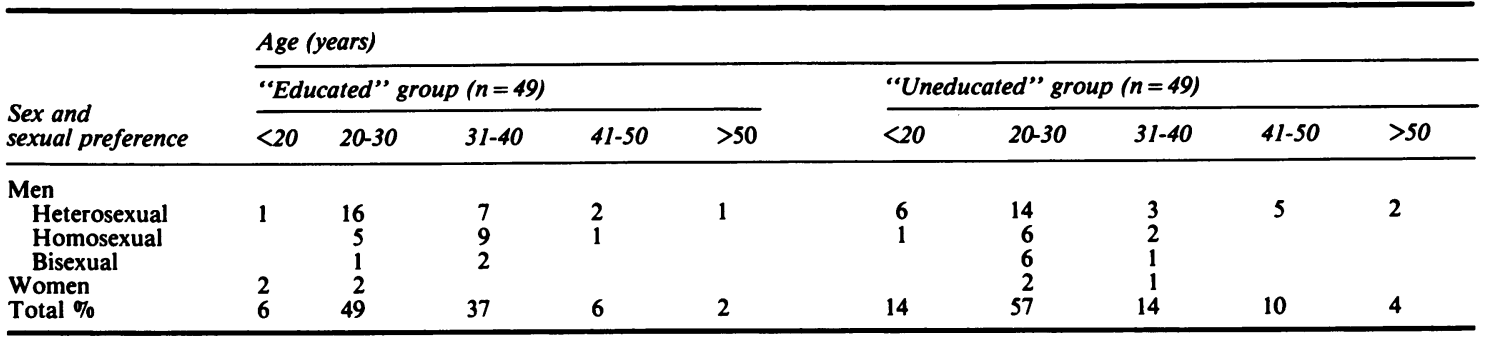

MARITAL STATE

The majority $(76 \%)$ of patients were single. This classification did not however differentiate between "single" and "living-with" status (table V).

\section{NATIONALITY}

The population of Paddington, where the Praed Street Clinic is located, is very cosmopolitan; only $50 \%$ were British, $15 \%$ West Indian, and the remaining $35 \%$ a mixture of several different nationalities.

\section{EDUCATIONAL ACHIEVEMENT}

A large proportion (25\%) of the patients had a university degree. An almost equal number (23\%) had left school before the age of 16 . Of the remainder, $17 \%$ had been to a technical college or undergone some further education, $12 \%$ had attained " $A$ " levels, 15\% " $O$ " levels, and $6 \%$ "CSE" (table VI).

\section{OCCUPATION/CLASS}

The scale devised by Perfrement and Overfield ${ }^{4}$ was used in assigning patients in both groups to one of the following occupation/class categories:

(1) Higher professional (for example, company director, lecturer);

(2) Lower professional (for example, nurse, librarian, insurance broker);

(3) Clerical (for example, telephonist, bank clerk);

(4) Manual (for example, driver, postman, machinist);
(5) Unemployed;

(6) Student;

(7) Housewife (not otherwise employed).

Formerly gonorrhoea was a disease primarily of promiscuous individuals of low socioeconomic status but it now occurs in all classes. In this study the most common categories were lower professional $(31 \%)$ and manual $(27 \%)$; the student category was also well represented $(18 \%)$ as was the clerical $(18 \%)$. There were no patients in categories (5) and (7).

\section{PATIENT COMPLIANCE}

The number of follow-up appointments attended by patients in the two groups is given in table VII. The "educated" patients had a lower default rate than the "uneducated." Furthermore, $25 \%$ of the "uneducated" but only $10 \%$ of the "educated" group did not return to the clinic at all. The two groups each contained nine patients who kept all their appointments; they did so because they continued to have symptoms due to the development of post-gonococcal (non-specific) urethritis. In the "uneducated" group, $8 \%$ returned with evidence of gonococcal reinfection.

\section{STATISTICAL ANALYSIS}

When the two groups are compared at each stage there is no significant difference in the proportion of non-attenders, except that a significantly higher proportion of "educated" than "uneducated" patients returned either once, twice, or three times compared with those who never reattended or who developed complications $\left(\alpha^{2} 7 \cdot 04, \mathrm{P}<0 \cdot 01\right)$.

TABLE V Marital state of all patients

\begin{tabular}{|c|c|c|c|c|c|c|}
\hline \multirow[b]{2}{*}{$\begin{array}{l}\text { Sex and } \\
\text { sexual preference }\end{array}$} & \multicolumn{3}{|c|}{ "Educated" group $(n=49)$} & \multicolumn{3}{|c|}{ "Uneducated" group $(n=49)$} \\
\hline & Married & Single & $\begin{array}{l}\text { Divorced/ } \\
\text { widowed/ } \\
\text { separated }\end{array}$ & Married & Single & $\begin{array}{l}\text { Divorced/ } \\
\text { widowed/ } \\
\text { separated }\end{array}$ \\
\hline \multicolumn{7}{|l|}{ Men } \\
\hline Heterosexual & 6 & 16 & 5 & 7 & 21 & 2 \\
\hline Homosexual & & 15 & & & 8 & 1 \\
\hline Bisexual & & 2 & 1 & 1 & 6 & \\
\hline Women & & 4 & & & 3 & \\
\hline Total \% & 12 & 76 & 12 & 16 & 78 & 6 \\
\hline
\end{tabular}


TABLE VI Educational achievement

\begin{tabular}{|c|c|c|c|c|c|c|}
\hline Group & $\begin{array}{l}\text { University } \\
\text { degree }\end{array}$ & $\begin{array}{l}\text { Other } \\
\text { degree/diploma* }\end{array}$ & $\begin{array}{l}\text { "A" level } \\
\text { certificate }\end{array}$ & $\begin{array}{l}\text { "O" level } \\
\text { certificate }\end{array}$ & $C S E$ & $\begin{array}{l}\text { Left school } \\
\text { at }<16 \text { years }\end{array}$ \\
\hline \multicolumn{7}{|l|}{ "Educated" } \\
\hline $\begin{array}{l}\text { Heterosexual } \\
\text { Homosexual } \\
\text { Bisexual }\end{array}$ & $\begin{array}{l}6 \\
4 \\
1\end{array}$ & $\begin{array}{l}4 \\
3 \\
1\end{array}$ & $\begin{array}{l}2 \\
4\end{array}$ & $\begin{array}{l}4 \\
2\end{array}$ & $\begin{array}{l}2 \\
1\end{array}$ & $\begin{array}{l}9 \\
1\end{array}$ \\
\hline $\begin{array}{l}\text { Women } \\
\text { Total \% }\end{array}$ & 29 & 18 & $\begin{array}{l}3 \\
6\end{array}$ & $\begin{array}{r}1 \\
16\end{array}$ & 6 & 25 \\
\hline $\begin{array}{l}\text { "Uneducated" } \\
\text { Men }\end{array}$ & & & & & & \\
\hline $\begin{array}{l}\text { Heterosexual } \\
\text { Homosexual } \\
\text { Bisexual } \\
\text { Women } \\
\text { Total \% }\end{array}$ & $\begin{array}{r}7 \\
3 \\
4 \\
29\end{array}$ & $\begin{array}{l}4 \\
3 \\
2\end{array}$ & $\begin{array}{l}2 \\
1\end{array}$ & $\begin{array}{r}3 \\
1 \\
1 \\
3 \\
16\end{array}$ & 3 & $\begin{array}{r}11 \\
1\end{array}$ \\
\hline
\end{tabular}

-Technical college or other higher educational course

CSE = certificate of secondary education

TABLE VII No of follow-up attendances in both groups

Additional factors No of follow-up attendances (3 attendances)

\begin{tabular}{|c|c|c|c|c|c|c|}
\hline Group & 0 & 1 & 2 & 3 & $P G U$ & Other \\
\hline \multicolumn{7}{|l|}{ "Educated" } \\
\hline \multicolumn{7}{|l|}{ Men } \\
\hline Heterosexual & 3 & 7 & 6 & 2 & 9 & \\
\hline Homosexual & 1 & 6 & 4 & 4 & & \\
\hline Bisexual & & 1 & & 2 & & \\
\hline Female & 1 & & 2 & $1^{*}$ & & \\
\hline Total \% & 10 & 29 & 25 & 18 & 18 & \\
\hline \multirow{2}{*}{\multicolumn{7}{|c|}{ "Uneducated" }} \\
\hline \multicolumn{6}{|l|}{ Men } & \\
\hline Heterosexual & 5 & 6 & 6 & 4 & 5 & $4 t$ \\
\hline Homosexual & 3 & 1 & 1 & 2 & 1 & $1 \neq$ \\
\hline Bisexual & 3 & $i$ & & & 2 & 1 \\
\hline Female & 1 & & & & $1^{*}$ & 18 \\
\hline Total \% & 25 & 16 & 14 & 12 & 18 & $14^{\circ}$ \\
\hline
\end{tabular}

*Epidemiological treatment

tReinfection

\#Warts

§Psychological problems

\section{Discussion}

The responses to questions asked of the "uneducated" group showed that the major source of information on sexually transmitted diseases was the peer group. Patients acknowledged that information gained in this manner was inaccurate and most were ignorant of the nature of their disease, possible complications, transmission, and treatment.

The clinic, which is separate from, but part of, the main hospital, was well accepted by the patients. There is no appointment system. It has separate waiting areas for men and women and patients are called by number. Most patients stated that they were unconcerned at the idea of attending a special clinic but at the same time they all preferred to be called by number rather than by name. Several commented that the absence of moral censure among the staff at the clinic was greatly appreciated.

The results of the study suggest that in patients with gonorrhoea compliance with a request to return for routine follow-up can be influenced through educational counselling. However, the study equally demonstrated that attendance is very much influenced by the persistence of symptoms and hence the need for active treatment. Educational counselling is, however, time-consuming. Approximately $25 \mathrm{~min}$ utes was spent with each patient interviewed. A larger study would have to be undertaken before it could be concluded that the increased compliance found in this study justified the cost in time and money that such routine counselling would entail.

I wish to thank the staff of the Praed Street Clinic, St Mary's Hospital, and in particular to Dr JRW Harris, for their kind help and co-operation in this study.

\section{References}

1. International Symposium on Gonorrhoea Information Canada, Ottawa, 1975 Cat. No H47-5/1975.

2. Department of Health and Social Security. Sexually transmitted diseases: extract from the Annual Report of the Chief Medical Officer of the Department of Health and Social Security for the year 1972. Br J Vener Dis 1974;50:73.

3. Hunter I, Jacobs J, Kinnell H, Satin A. In: Handbook on Contact Tracing in Sexually Transmitted Diseases, 1980:81-103.

4. Perfrement $S$, Overfield $K$. Which patients with sexually transmitted disease default? $B r J$ Vener Dis 1978;54:203-4. 